\title{
Wydzielanie i charakterystyka frakcji pylastej (silt) w skałach mułowcowych zapadliska przedkarpackiego
}

\begin{abstract}
Skały mułowcowe, pomimo że zawierają znacznie mniej minerałów ilastych niż iłowce, to na krzywych otworowych mają podobny poziom radioaktywności, co istotnie utrudnia wydzielenie ich z analizowanego profilu litologicznego. Celem przedstawionych badań jest opracowanie metodyki pozwalającej na wydzielenie, charakterystykę i oszacowanie ilościowego udziału frakcji pylastej (silt) w skałach mułowcowych. Przetestowane zostały różne laboratoryjne metody rozdrabniania skał (kruszenie, zamrażanie, nasycanie solą glauberską) tak, aby uniknąć sztucznego utworzenia dodatkowego siltu (np. przez zbytnie rozkruszenie skały), jak i zaniżenia jego ilości (przez niedostateczne rozdrobnienie skały). Poszczególne frakcje ziarnowe zostały wydzielone w rozdrobnionym materiale skalnym metodą sitową (frakcja piaszczysta) oraz metodą wirowania (frakcja pylasta, frakcja ilasta). Następnie przeprowadzono dokładną charakterystykę mineralogiczną i petrofizyczną oraz dokonano oceny ilościowej wydzielonej frakcji pylastej. Wydzielenie frakcji pylastej badanych skał i uwzględnienie jej w modelach interpretacyjnych umożliwia rozróżnienie mułowców i iłowców w profilach otworów wiertnicznych zapadliska przedkarpackiego.
\end{abstract}

Słowa kluczowe: silt, frakcja pylasta, metody rozdrabniania skał.

\section{Separation and characterization of the silt fraction in the mudstone rocks of the Carpathian Foredeep}

Mudstones, although they contain significantly less clay minerals than claystones, they exhibit similar levels of radioactivity on the well logs, which significantly impedes their distinction in the analyzed lithological profile. The aim of the study was to develop a methodology for separating, characterizing, and estimating the amount of silt fraction in mudstone rocks. Various laboratory methods of fragmentation (crushing, freezing, saturation with Glauber's salt) have been tested to avoid both creating additional silt artificially (e.g. by over-crushing the rock), and underestimating of its amount (by insufficient fragmentation of rocks). The individual grain fractions were separated in the crushed rock material by the sieve (sand fraction) and centrifugation methods (silt fraction, clay fraction). Subsequently the detailed mineralogical and petrophysical characteristics and quantitative evaluation of the silt fraction were carried out. The separation of the silt fraction in the examined rock and its inclusion in the interpretation models will allow to distinguish between mudstones and claystones in the profiles of the Carpathian Foredeep boreholes.

Key words: silt, silt fraction, methods of fragmentation rocks.

\section{Wprowadzenie}

Mułowce w porównaniu z iłowcami, zawierają mniej minerałów ilastych, jednak na radiometrycznych pomiarach otworowych wykazują podobny poziom radioaktywności, co istotnie utrudnia wydzielenie ich $\mathrm{z}$ analizowanego profilu litologicznego. Skały mułowcowe zawierają duże ilości frakcji pylastej, głównie krzemionkowej, znacząco wpływającej na ich właściwości petrofizyczne - odróżniając je od silnie zailonych skał iłowcowych i drobno ziarnistych piaskowców. Ilościowa ocena zawartości frakcji pylastej w badanej skale oraz określenie jej właściwości na drodze laboratoryjnej, pozwoliłyby na uwzględnienie tej frakcji w modelu interpretacyjnym skały i prawidłowe oszacowanie zailenia oraz parametrów złożowych, takich jak porowatość efektywna czy nasycenie mediami złożowymi.

Do wyznaczenia właściwości petrofizycznych dla pelitycznych składników, można wykorzystać badania laboratoryjne. Opracowanie metodyki określania właściwości składników pelitycznych, ocena ich wpływu na pomiary geofizyczne oraz określenie relacji z parametrami zbiornikowymi formacji, umożliwiłyby dokładniejszą ilościową analizę nie tylko 
mułowców, ale również innych, interesujących typów skał jak łupki czy margle, będących obecnie przedmiotem zainteresowania w poszukiwaniach węglowodorów. Celem pracy było stworzenie metodyki pozwalającej na wydzielenie frakcji pylastej (silt) w skałach mułowcowych zapadliska przedkarpackiego. Wykonano szereg prac laboratoryjnych, których wynikiem jest dokładna charakterystyka skał mułowcowych, zarówno mineralogiczna, jak i petrofizyczna. Złożoność problematyki oraz brak zadowalającej metodyki prac laboratoryjnych, która pozwoliłaby na określenie parametrów petrofizycznych frakcji pylastej wymagała wykonania wielu czasochłonnych testów, mających charakter prac podstawowych. Zakres prac obejmowat:

- dobór materiału do badań i charakterystykę badanych skał (badania mikroskopowe, analiza XRD, pomiary EDXRF),

- testowanie różnych metod rozdrabniania skał (rozkruszanie, zamrażanie, nasycanie solą glauberską),
- rozdzielanie uzyskanych frakcji ziarnowych metodą sitową i wirowania,

- szacowanie ilościowe uzyskanych frakcji,

- charakterystykę mineralogiczną i petrofizyczną uzyskanych frakcji (badania mikroskopowe, analiza XRD, pomiary EDXRF, wyznaczenie gęstości, wyznaczenie współczynnika wymiany kationowej CEC, pomiary radiometryczne). W prowadzonych na świecie od końca XIX wieku badaniach osadów klastycznych stosowane są różne klasyfikacje frakcjonalne służące do analiz uziarnienia, a na tej podstawie oznaczania typów osadów. W klasyfikacjach tych używane są zarówno różne przedziały pomiędzy poszczególnymi frakcjami, jak i różne nazwy frakcji [11]. Powołując się na badania prowadzone przez Peveraro i Thomasa [7] w niniejszej pracy, za najbardziej odpowiednią do badań skał mułowcowych uznano klasyfikację Wentwortha [13], przyjmując wielkość frakcji siltowej $0,004 \div 0,063 \mathrm{~mm}$.

\section{Metodyka badań}

W celu opracowania metodyki wydzielania frakcji pylastej (siltu) wytypowano materiał do badań. Są to rdzenie wiertnicze pochodzące z otworów z rejonu zapadliska przedkarpackiego. Wykonano dokumentację fotograficzną rdzeni oraz opis litologiczny, który zamieszczono w tablicy 1 .

Etap 1 - rozdrabnianie materiału. Wytypowany materiał do badań poddano trzem sposobom rozdrabniania: rozkruszaniu, zamrażaniu, nasycaniu solą glauberską (sodu siarczan(VI) bezw. $\mathrm{Na}_{2} \mathrm{SO}_{4}$ ).

- Rozkruszanie - materiał rozbito za pomocą młotka, a następnie przesiano przez sito $0,5 \mathrm{~mm}$.

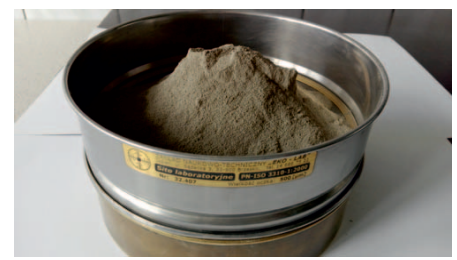

Rys. 1. Widok próbki rozkruszanej młotkiem i przesiewanej przez sito $0,5 \mathrm{~mm}$

- Zamrażanie [6] - próbkę umieszczono w pojemniku do zamrażania i zalano wodą destylowaną. Następnie całość umieszczono w zamrażalniku na 16 godzin. Po upływie
Tablica 1 . Wytypowany materiał do badań.

\begin{tabular}{|l|l|l|}
\hline & $\begin{array}{l}\text { Piaskowiec drobnoziarnisty, } \\
\text { jasnoszary. } \\
\text { Wtrącenia zwęglonej substancji } \\
\text { organicznej w postaci cienkich } \\
\text { laminek }\end{array}$ \\
\hline 6435 & & $\begin{array}{l}\text { Mułowiec szary z przekładkami } \\
\text { piaskowca. Warstwowany } \\
\text { równolegle }\end{array}$ \\
\hline
\end{tabular}

tego czasu próbkę rozmrożono. Proces zamrażania i rozmrażania powtarzano przez $7 \mathrm{dni}$, do momentu uzyskania konsystencji papki.

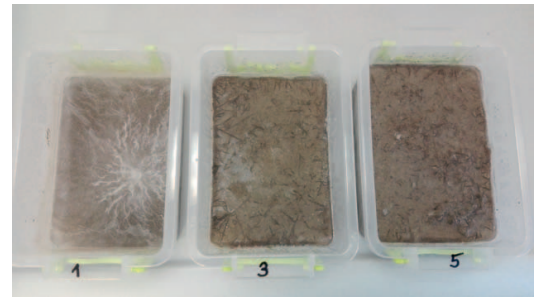

Rys. 2. Widok próbek po zamrożeniu

- Nasycanie solą glauberską [2] - próbki umieszczono w zlewkach, zasypano kilkoma łyżkami soli glauberskiej 
i zalano wodą destylowaną. Całość umieszczono na łaźni wodnej, aż do momentu rozpuszczenia się soli. Następnie próbki zdjęto z łaźni wodnej i pozostawiono pod dygestorium na 16 godzin w celu wykrystalizowania się soli. Proces rozpuszczania i krystalizacji powtarzano przez siedem dni.
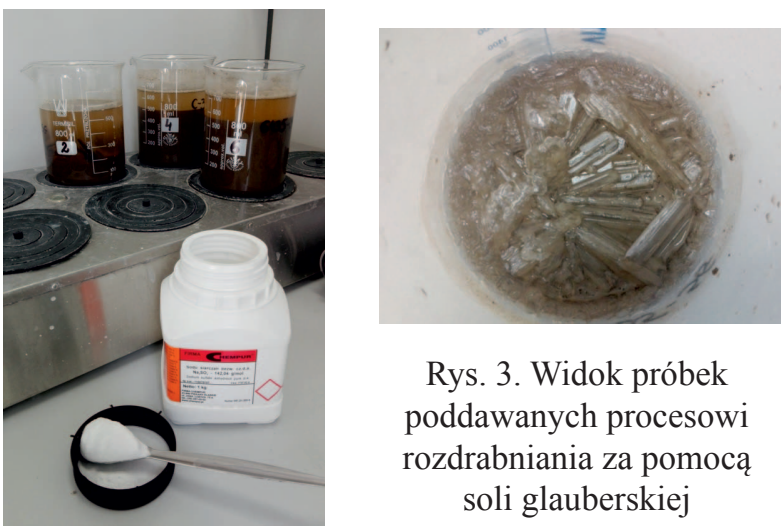

Rys. 3. Widok próbek poddawanych procesowi rozdrabniania za pomocą soli glauberskiej

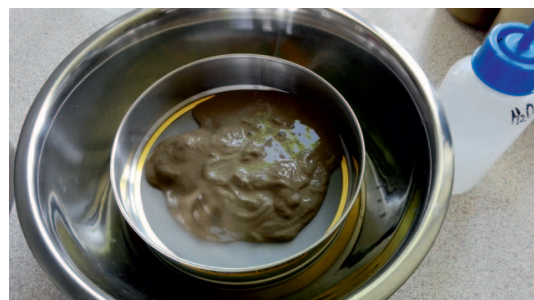

Rys. 4. Widok próbki przesiewanej na mokro

Następnie próbki poddano procesowi oczyszczania z soli $[3,5]$. W tym celu przeniesiono je do pojemników do wirowania. Pojemniki uzupełniono i zrównoważono wodą destylowaną. Próbki wirowano przez 10 min przy 2500 obrotach/min. Ciecz znad osadu zlewano, a próbki po raz kolejny zalewano wodą destylowaną. Wirowania powtarzano, aż do całkowitego wyczyszczenia próbek z soli, czyli do momentu, aż próbka nie osiadła na dnie pojemnika. Próbki po wysuszeniu ( $\left(\mathrm{w} 60^{\circ} \mathrm{C}\right)$ uległy ,zbryleniu”. W związku z tym, nie było możliwości wykonania badań mineralogicznych i petrofizycznych na próbkach rozdrabnianych za pomocą soli glauberskiej przed podziałem na frakcje.

Etap 2 - odsianie z próbki frakcji powyżej $0,063 \mathrm{~mm}$. Próbki poddawane procesowi zamrażania oraz próbki rozdrabniane

za pomocą soli glauberskiej przesiano na mokro przez sito $0,063 \mathrm{~mm}$.

Etap 3 - odwirowywanie frakcji ilastej $<4 \mathrm{~m}[3,5,12]$. Próbki przeniesiono do pojemników do wirowania. Pojemniki uzupełniono do wysokości zaznaczonej na pojemnikach i zrównoważono wodą destylowaną. Odwirowywanie frakcji $<4 \mu \mathrm{m}$ prowadzono przez $4 \mathrm{~min}$ przy $500 \mathrm{obrotach} / \mathrm{min}$. Roztwór znad osadu zlano, a pojemniki ponownie uzupełniono wodą destylowaną. Wirowanie powtarzano do momentu, aż zlewany roztwór był względnie przeźroczysty.

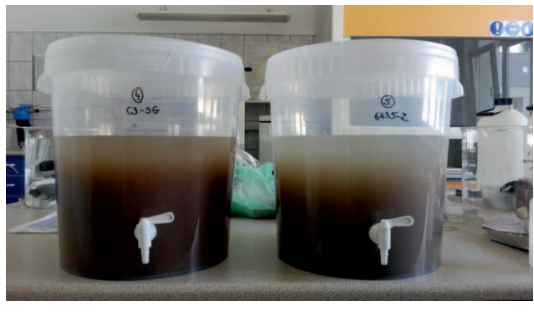

Etap 4 - sedymentacja. Próbki przeniesiono do pojemników do sedymentacji i zalano wodą destylowaną. Po kilku godzinach, gdy osad opadł poniżej kranika, roztwór znad osadu zlewano. Sedymentację powtarzano dwukrotnie.

Etap 5 - suszenie próbek w $60^{\circ} \mathrm{C}$. Próbki po sedymentacji przeniesiono do zlewek i umieszczono w suszarce na kilka dni, aż do całkowitego wysuszenia.

\section{Wyniki badań laboratoryjnych}

Przeprowadzona została dokładna charakterystyka mineralogiczna i petrofizyczna próbek rozdrabnianych różnymi metodami przed rozdziałem na frakcje (za wyjątkiem próbek nasycanych solą glauberską 6435 SG, C-3 GS, 5719 SG, które po wysuszeniu w $60^{\circ} \mathrm{C}$ uległy ,zbryleniu”) i na wydzielonej frakcji pylastej (silt).

Tablica 2. Skład mineralny analizowanych próbek

\begin{tabular}{|c|c|c|}
\hline Grupa & Próbki przed rozdziałem na frakcje & Wydzielona frakcja pylasta (silt) \\
\hline I piaskowce & $\begin{array}{l}\text { Średnio około } 53 \% \text { kwarcu, } 10 \% \text { plagioklazów, } \\
7,5 \% \text { skaleni potasowych, } 3,9 \% \text { kalcytu, } 4,2 \% \text { dolomitu, } \\
0,9 \% \text { ankerytu, } 1 \% \text { pirytu, } 19 \% \text { minerałów ilastych }\end{array}$ & $\begin{array}{l}\text { Średnio około } 44,7 \% \text { kwarcu, } 12,2 \% \text { plagioklazów, } \\
6,3 \% \text { skaleni potasowych, } 6 \% \text { kalcytu, } 4,8 \% \text { dolomitu, } \\
1,4 \% \text { ankerytu, } 1,1 \% \text { pirytu, } 25,7 \% \text { minerałów ilastych }\end{array}$ \\
\hline $\begin{array}{l}\text { II mułowce } \\
\text { z wkładkami } \\
\text { piaskowca }\end{array}$ & $\begin{array}{l}\text { Średnio około } 26,5 \% \text { kwarcu, } 8 \% \text { plagioklazów, } \\
5 \% \text { skaleni potasowych, } 7,9 \% \text { kalcytu, } 5,6 \% \text { dolomitu, } \\
1,4 \% \text { ankerytu, } 1,2 \% \text { pirytu, } 44,3 \% \text { minerałów ilastych }\end{array}$ & $\begin{array}{l}\text { Średnio około } 31,9 \% \text { kwarcu, } 9,8 \% \text { plagioklazów, } \\
4,9 \% \text { skaleni potasowych, } 8,4 \% \text { kalcytu, } 7,6 \% \text { dolomitu, } \\
1,7 \% \text { ankerytu, } 1,2 \% \text { pirytu, } 34,6 \% \text { minerałów ilastych }\end{array}$ \\
\hline III mułowce & $\begin{array}{l}\text { Średnio około } 21,5 \% \text { kwarcu, } 6 \% \text { plagioklazów, } \\
4,3 \% \text { skaleni potasowych, } 8,9 \% \text { kalcytu, } 4,9 \% \text { dolomitu, } \\
1,4 \% \text { ankerytu, } 6,2 \% \text { pirytu, } 51 \% \text { minerałów ilastych }\end{array}$ & $\begin{array}{l}\text { Średnio około } 27,9 \% \text { kwarcu, } 8,5 \% \text { plagioklazów, } \\
4,9 \% \text { skaleni potasowych, } 10,3 \% \text { kalcytu, } 7,2 \% \text { dolomitu, } \\
1,6 \% \text { ankerytu, } 2,3 \% \text { pirytu, } 37,4 \% \text { minerałów ilastych }\end{array}$ \\
\hline
\end{tabular}




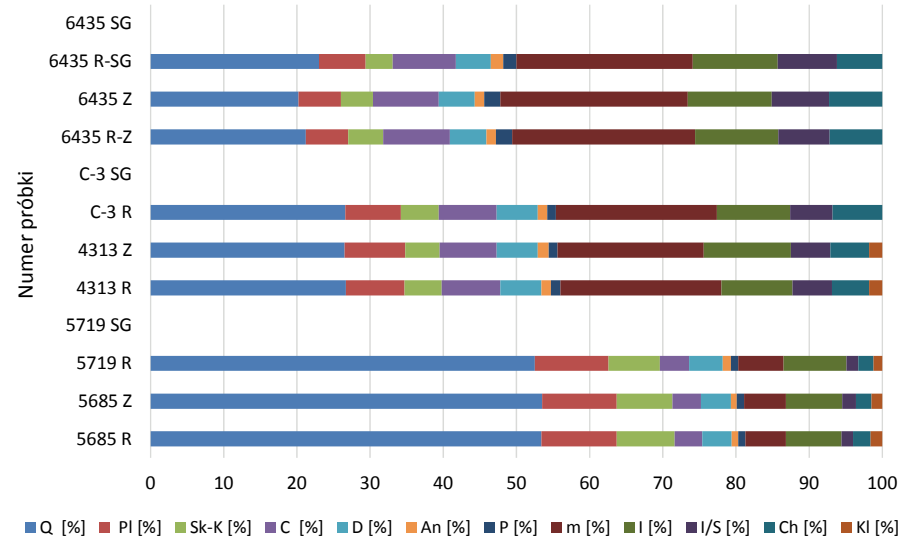

Rys. 6. Skład mineralny próbek przed rozdziałem na frakcje

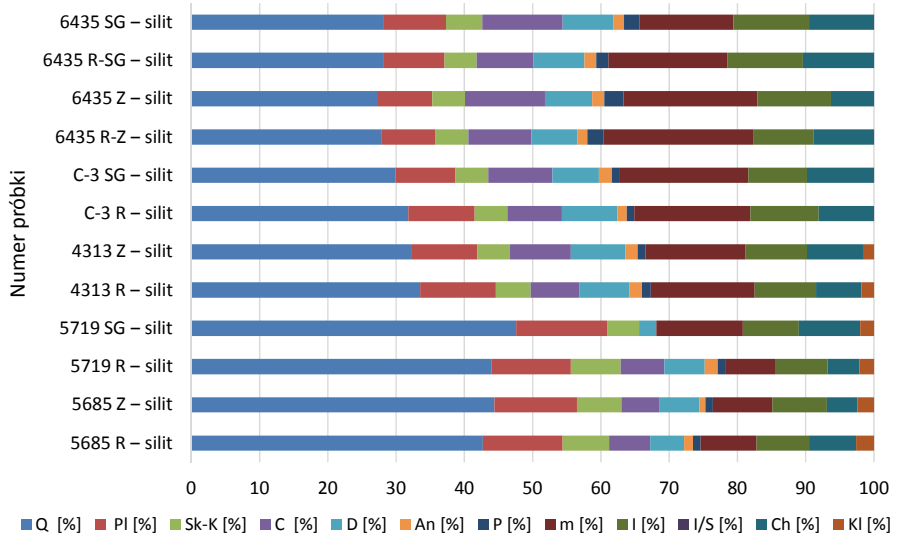

Rys. 7. Skład mineralny dla wydzielonej frakcji pylastej (silt)

Oznaczenia: Q - kwarc, 33-1161; Pl - plagioklazy; Sk-K - skalenie potasowe; C - kalcyt, 5-586; D - dolomit, 36-426; An - ankeryt, 33-282; P - piryt, 6-710; m - miki, I - illit; I/S - minerał mieszanopakietowy illit-smektyt; Ch - chloryt; K1 - kaolinit, 29-1488.

Ilościową analizę składu mineralnego skał wyliczono metodą Rietvelda przy pomocy programu komputerowego SIROQUANT [5]. Wyniki przedstawiono w tablicy 2 oraz na rysunkach 6 i 7. Dodatkowo wykonano pomiary składu chemicznego próbek skał metodą fluorescencji rentgenowskiej (EDXRF) w celu weryfikacji poprawności identyfikacji składników mineralnych próbki [10]. Skład frakcji pylastej (siltu) jakościowo odpowiada składowi całej próbki. Jest zubożony o grubokrystaliczny kwarc i minerał mieszanopakietowy (pęczniejący) illit-smektyt. Wykonano również ilościową analizę składu mineralnego dla wydzielonej frakcji $<4 \mu \mathrm{m}$, która potwierdziła słuszność przeprowadzenia sedymentacji dla zastosowanej metodyki wydzielania frakcji pylastej.

Badania SEM-EDS wykonano dla wybranych próbek reprezentujących poszczególne litologie (piaskowiec, mułowiec/ piaskowiec, mułowiec). Skład mineralny próbki, który okre- ślono metodą XRD, został potwierdzony na podstawie punktowych analiz składu chemicznego wykonanych przy pomocy mikrosondy. Zaobserwowano, że rozmiary ziaren mieszczą się w zakresie wielkości ziaren wydzielonej frakcji $(4 \div 63 \mu \mathrm{m})$. Przykładowe fotografie z mikroskopu skaningowego przedstawiono na rysunkach 8-11. Zaznaczono punkty, w których wykonano analizę EDS.

Pomiary gęstości przeprowadzono na próbkach rozdrabnianych różnymi metodami, zarówno przed rozdziałem na frakcje, jak i na wydzielonej frakcji pylastej (silt). Wyniki zaprezentowano na rysunku 12.

Na podstawie rysunku 12 zaobserwować można, że wartości gęstości dla wydzielonej frakcji pylastej są wyższe w porównaniu z gęstością pomierzonych na próbkach przed rozdziałem na frakcje. Wyjątek stanowią tu trzy próbki (4313 R, C-3 R, 6435R-Z) rozkruszone za pomocą młotka.
MUŁOWIEC

Z WKŁADKAMI PIASKOWCA

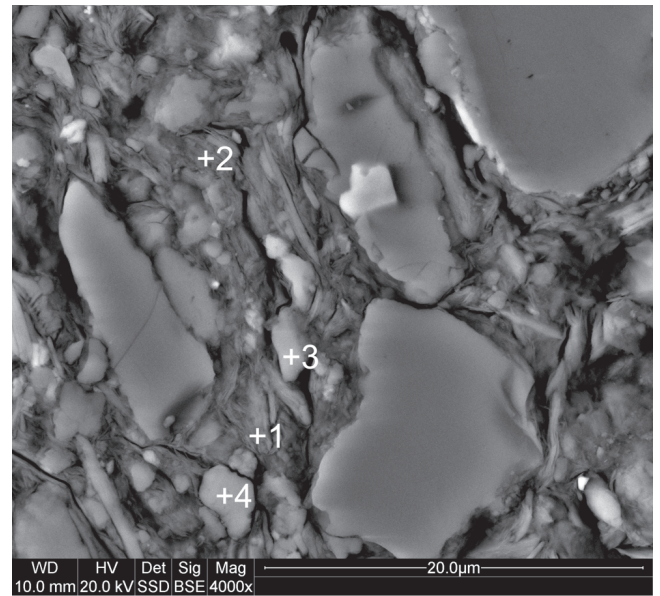

Rys. 8. Płytka cienka, obraz przy powiększeniu 4000x. Skala zaznaczona pod zdjęciem. Matriks wypełniające przestrzeń porową złożone $\mathrm{z}$ minerałów ilastych (p1, p2), drobnych blaszek mik i drobnych ziaren kwarcu (p3) oraz skalenia (p4)

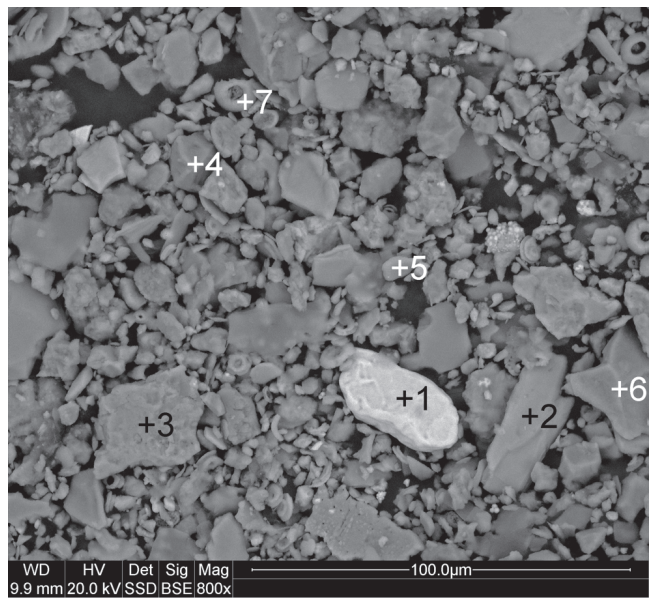

Rys. 9. Wydzielona frakcja pylasta (silt), próbka rozdrabniana poprzez zamrażanie. Występują tutaj kwarc (p6), węglany (p3, p7), skalenie (p4), miki (p2, p5), minerały ciężkie (p1) 
MUŁOWIEC

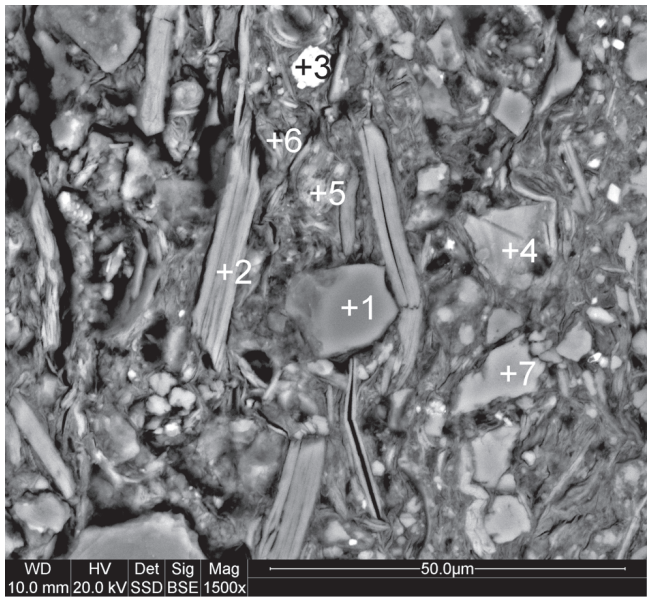

Rys. 10. Płytka cienka, obraz przy powiększeniu 1500x.

Skala zaznaczona pod zdjęciem. Zaobserwowano ziarna kwarcu (p1), miki (p2), skalenie (p7), minerały ilaste (p5, p6), piryt (p3), apatyt (p4)

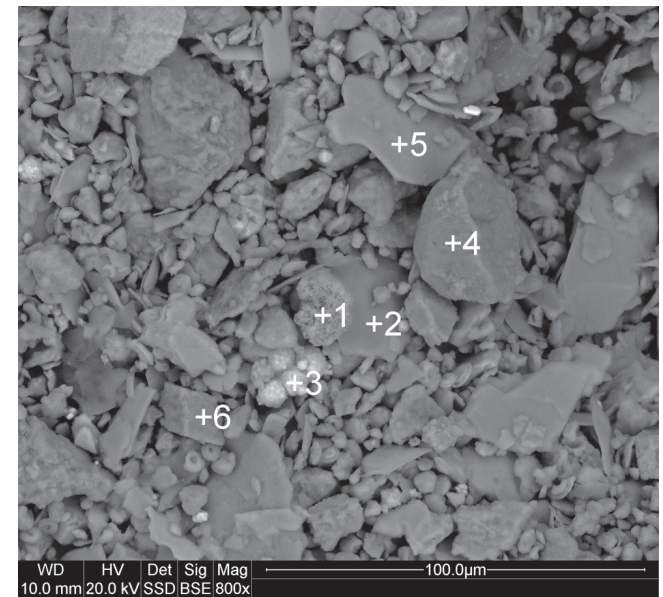

Rys. 11. Wydzielona frakcja pylasta (silt), próbka rozdrabniana poprzez zamrażanie.

Zaobserwowano ziarna kwarcu (p4), skaleni (p2), węglanów (p1, p6), piryt (p3), miki (p5)

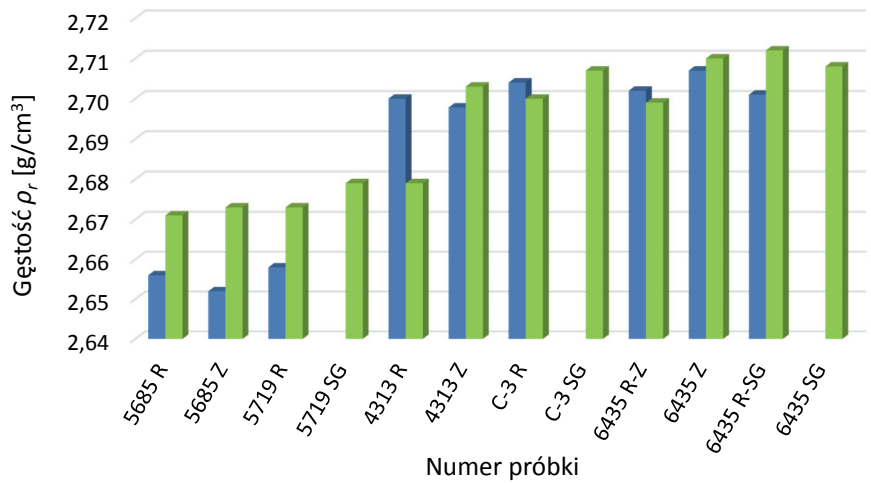

Rys. 12. Wartości gęstości dla próbek przed rozdziałem na frakcje (kolor niebieski) i dla wydzielonej frakcji pylastej (kolor zielony)

Pomiar CEC wykonano metodą heksaaminy kobaltowej [8]. Pojemność wymiany kationowej jest ściśle związana $\mathrm{z}$ ilością i rodzajem minerałów ilastych, charakteryzujących się, ze względu na wielkość powierzchni właściwej, dużymi zdol-

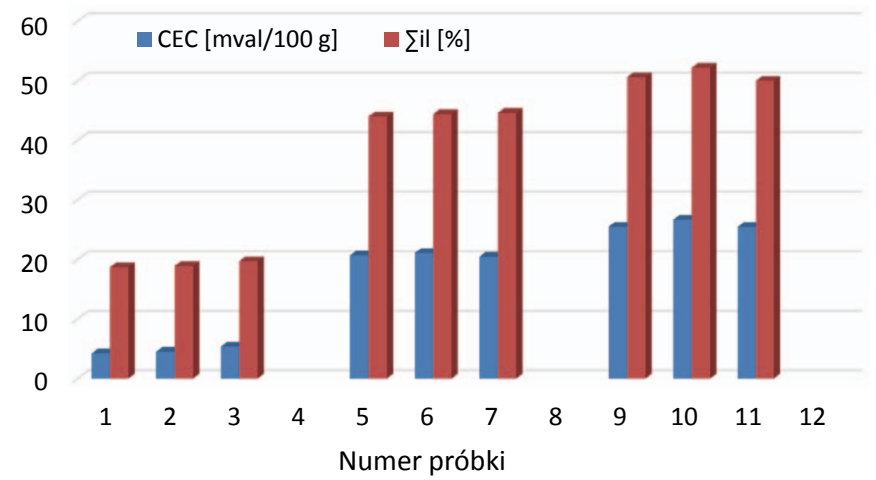

Rys. 13. Wartości pojemności wymiany kationowej (CEC) i sumy minerałów ilastych w analizowanych próbkach przed rozdziałem na frakcje; próbki 1-4 piaskowce, próbki 5-8 mułowce z wkł. piaskowca, próbki 9-12 mułowce nościami jonowymiennymi. Wyniki przedstawiono na rysunkach 13 i 14.

Przedstawione zależności dobrze ilustrują to, że parametr CEC odzwierciedla własności pęczniejące iłów. Na rysunkach 13 i 14 widoczna jest zależność pomiędzy zawartością minerałów ilastych a wartością pojemności wymiany kationowej - parametr ten wyraźnie rośnie wraz ze wzrastającą zawartością sumy minerałów ilastych.

Badania petrofizyczne obejmowały również wykonanie pomiarów zawartości pierwiastków promieniotwórczych: uranu, toru i potasu. Naturalna promieniotwórczość skał (Th, U, K) jest ściśle związana ze składem mineralnym oraz zawartością substancji organicznej [1]. Źródłem potasu są miki, minerały ilaste, takie jak illit i minerały mieszanopakietowe illit-smektyt oraz skalenie potasowe. Tor występuje w minerałach ilastych oraz minerałach ciężkich, natomiast podwyższone zawartości uranu widoczne są w skałach zawierających fosforany (apatyty-fosforan wapnia), uran związany jest tak-

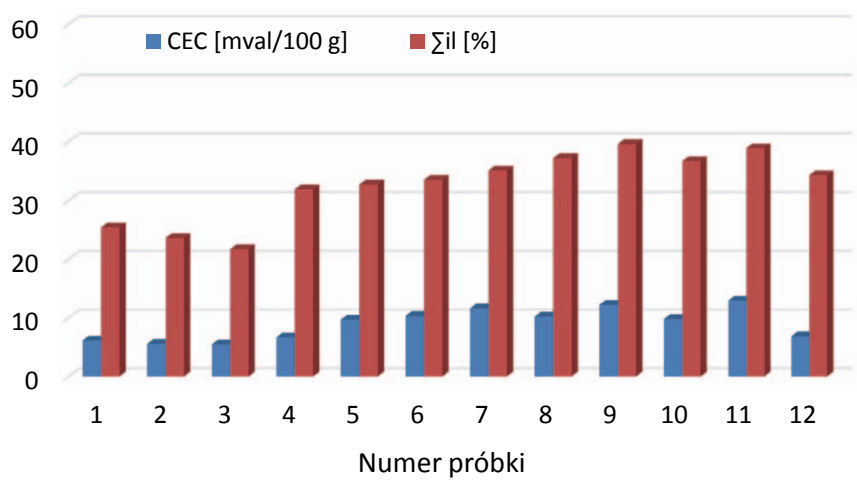

Rys. 14. Wartości pojemności wymiany kationowej (CEC) i sumy minerałów ilastych dla wydzielonej frakcji pylastej (silt); próbki 1-4 piaskowce, próbki 5-8 mułowce z wkł. piaskowca, próbki 9-12 mułowce 
że z substancją organiczną [9]. Zarówno tor, jak i potas mogą służyć jako wskaźnik zailenia. Zawartości pierwiastków pro- mieniotwórczych dla badanych próbek przedstawiono na rysunkach 15 i 16.

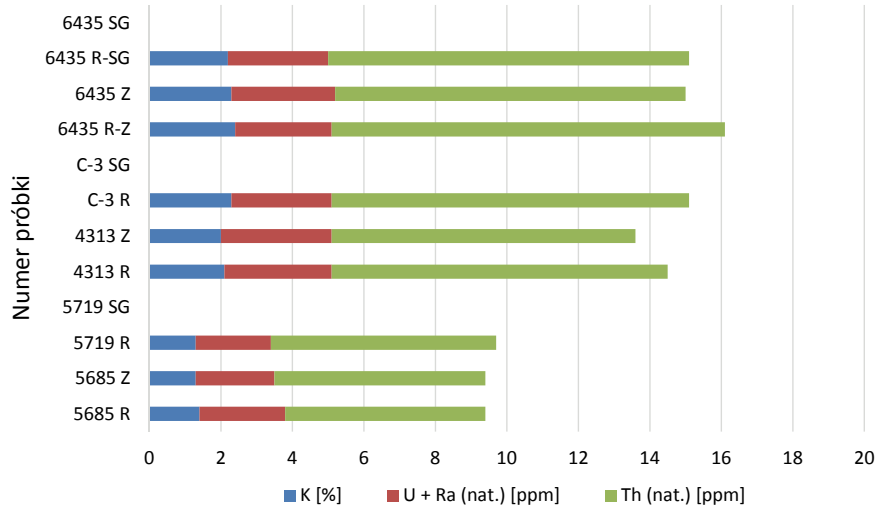

Rys. 15. Zawartości pierwiastków promieniotwórczych dla badanych próbek skał przed rozdziałem na frakcje

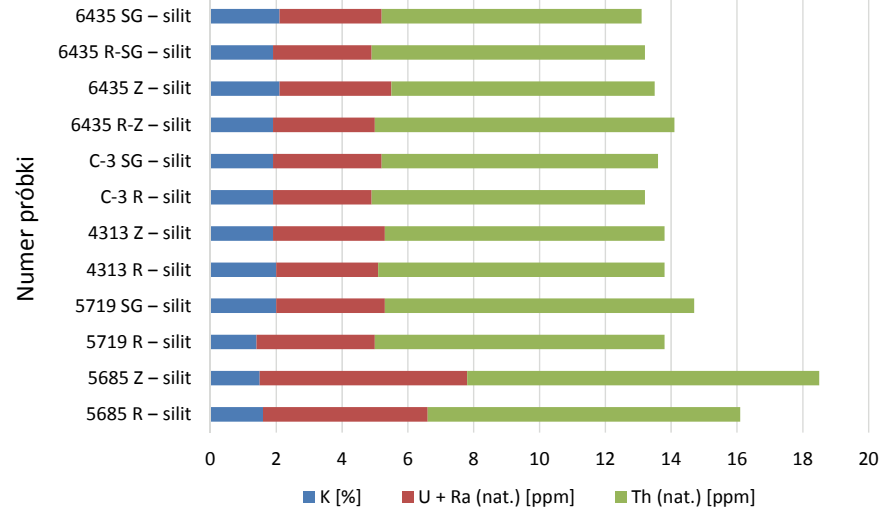

Rys. 16. Zawartości pierwiastków promieniotwórczych dla wydzielonej frakcji pylastej (silt)

\section{Analiza uzyskanych wyników pod kątem weryfikacji metodyki wydzielania frakcji pylastej}

Przetestowano trzy laboratoryjne metody rozdrabniania skały do wydzielania frakcji pylastej: rozkruszanie, zamrażanie, nasycanie solą glauberską. Badania skaningowe potwierdziły, że wszystkie metody umożliwiają uzyskanie frakcji pylastej $(4 \div 63 \mu \mathrm{m})$. Niemniej, w trakcie analizy ilościowych udziałów różnych frakcji uzyskanych dla badanych typów litologicznych, zaobserwowano pewne rozbieżności. Najwięcej wątpliwości budzi metoda rozkruszania. Jedynie dla piaskowców (próbki 5685 i 5719) udziały frakcji > $63 \mu \mathrm{m}$ otrzy- mane zarówno metodą rozkruszania, jak i przez zamrażanie oraz nasycanie solą glauberską są porównywalne. Dla mułowców z laminami piaskowca (próbki 4313 i C-3) i dla mułowca (próbka 6435) zauważa się natomiast wyraźną różnicę w ilości frakcji $>63 \mu \mathrm{m}$ uzyskanej metodą rozkruszania w porównaniu z ilością otrzymaną metodami: zamrażania i nasycania solą glauberską. Metody zamrażania oraz nasycania solą glauberską dają znacząco niższy udział frakcji $>63 \mu \mathrm{m}$ dla skał piaszczysto-mułowcowych i mułowców, zachowując przy tym logicznie

Tablica 3. Oszacowanie udziału frakcji $>63 \mu \mathrm{m}$ oraz frakcji silt $(4 \div 63 \mu \mathrm{m}) \mathrm{w}$ badanych próbkach

\begin{tabular}{|c|c|c|c|c|c|c|c|c|}
\hline \multirow[t]{2}{*}{ Litologia } & \multirow[t]{2}{*}{$\begin{array}{l}\text { Numer } \\
\text { próbki }\end{array}$} & \multicolumn{2}{|c|}{ Oznaczenie metody } & \multirow{2}{*}{$\begin{array}{l}\text { Masa mate- } \\
\text { riału do wy- } \\
\text { dzielenia siltu } \\
{[\mathrm{g}]}\end{array}$} & \multirow{2}{*}{$\begin{array}{r}\text { Frakcja } \\
>63 \mu \mathrm{m} \\
{[\mathrm{g}]}\end{array}$} & \multirow{2}{*}{$\begin{array}{l}\text { Udział frakcji } \\
>63 \mu \mathrm{m} \\
\text { w próbce } \\
{[\%]}\end{array}$} & \multirow{2}{*}{$\begin{array}{l}\text { Frakcja silit } \\
\qquad 4 \div 63 \mu \mathrm{m} \\
{[\mathrm{g}]}\end{array}$} & \multirow{2}{*}{$\begin{array}{l}\text { Udział frakcji } \\
4 \div 63 \mu \mathrm{m} \\
\text { w próbce } \\
{[\%]}\end{array}$} \\
\hline & & & & & & & & \\
\hline Piaskowiec & 5685 & $\mathrm{R}$ & rozkruszanie & 214,71 & 112,17 & 52,24 & 63,39 & 29,5 \\
\hline Piaskowiec & 5685 & $\mathrm{Z}$ & zamrażanie & 310,79 & 163,31 & 52,55 & 72,85 & 23,4 \\
\hline Piaskowiec & 5719 & $\mathrm{R}$ & rozkruszanie & 196,58 & 105,14 & 53,48 & 60,57 & 30,8 \\
\hline Piaskowiec & 5719 & $\mathrm{SG}$ & sól glauberska & 500,00 & 278,07 & 55,61 & 93,76 & 18,8 \\
\hline $\begin{array}{c}\text { Mułowiec z wkł. } \\
\text { piaskowca }\end{array}$ & 4313 & $\mathrm{R}$ & rozkruszanie & 164,49 & 69,57 & 42,29 & 44,12 & 26,8 \\
\hline $\begin{array}{c}\text { Mułowiec } \mathrm{z} \text { wkł. } \\
\text { piaskowca }\end{array}$ & 4313 & Z & zamrażanie & 310,58 & 9,79 & 3,15 & 132,6 & 42,7 \\
\hline $\begin{array}{c}\text { Mułowiec } \mathrm{z} \text { wkł. } \\
\text { piaskowca }\end{array}$ & $\mathrm{C}-3$ & $\mathrm{R}$ & rozkruszanie & 262,98 & 115,86 & 44,06 & 76,25 & 29,0 \\
\hline $\begin{array}{c}\text { Mułowiec } \mathrm{z} \text { wkł. } \\
\text { piaskowca }\end{array}$ & $\mathrm{C}-3$ & SG & sól glauberska & 350,00 & 8,62 & 2,46 & 190,53 & 54,4 \\
\hline Mułowiec & 6435 & $\mathrm{R}-\mathrm{Z}$ & rozkruszanie & 375,70 & 224,65 & 59,80 & 68,56 & 18,2 \\
\hline Mułowiec & 6435 & $\mathrm{Z}$ & zamrażanie & 443,52 & 2,26 & 0,51 & 230,84 & 52,0 \\
\hline Mułowiec & 6435 & R-SG & rozkruszanie & 415,79 & 216,19 & 51,99 & 101,24 & 24,3 \\
\hline Mułowiec & 6435 & SG & sól glauberska & 550,00 & 4,71 & 0,86 & 254,32 & 46,2 \\
\hline
\end{tabular}



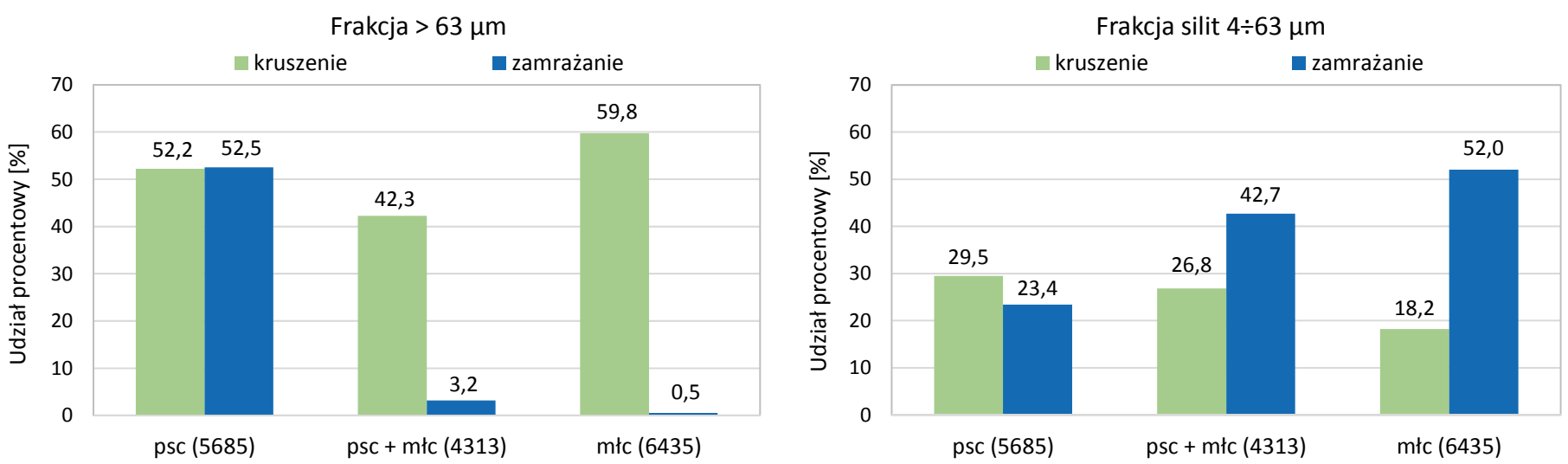

Rys. 17. Porównanie udziałów frakcji $>63 \mu \mathrm{m}$ i frakcji silt $(4 \div 63 \mu \mathrm{m})$ uzyskanych metodą rozkruszania i metodą zamrażania Objaśnienia: psc - piaskowiec, psc + młc - mułowiec $\mathrm{z}$ wkładkami piaskowca, młc - mułowiec.
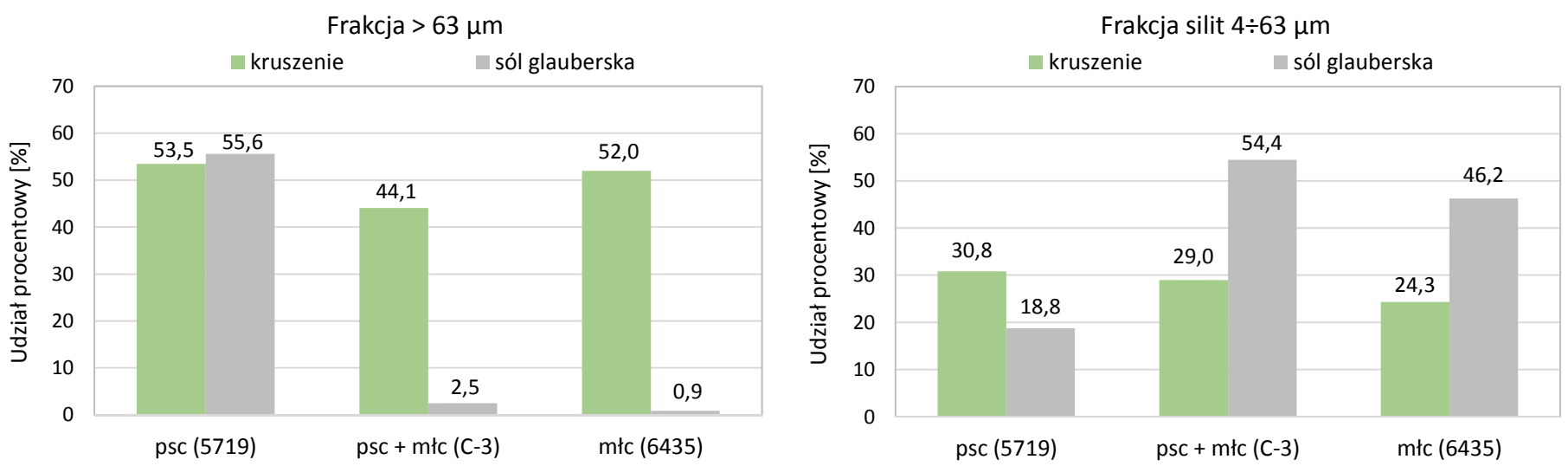

Rys. 18. Porównanie udziałów frakcji $>63 \mu \mathrm{m}$ i frakcji silt $(4 \div 63 \mu \mathrm{m})$ uzyskanych metodą rozkruszania i metodą nasycania solą glauberską

nieco wyższy udział tej frakcji w skałach piaszczysto-mułowcowych. W przypadku rozkruszania skał młotkiem udział frakcji $>63 \mu \mathrm{m}$ dla tych samych skał (mułowce z przekładkami piaskowców i mułowce) jest porównywalny, a nawet wyższy niż dla piaskowców (tablica 3, rysunki 17 i 18). Prawdopodobnie w czasie rozkruszania materiał nie został dostatecznie rozdrobniony, co spowodowało, że znacząca część siltu w postaci zlepionych ziaren znalazła się w masie frakcji $>63 \mu \mathrm{m}$. Ta sama przyczyna spowodowała zaniżenie udziału frakcji pylastej $(4 \div 63 \mu \mathrm{m})$ w skałach piaszczysto-mułowcowych i mułowcach. Proporcje frakcji uzyskanych dla poszczególnych typów litologicznych metodą zamrażania oraz przy użyciu soli glauberskiej wydają się być prawidłowe. Ze względu na dużo większą uciążliwość procedury badawczej w metodzie wykorzystującej sól glauberską (podgrzewanie na łaźni wodnej, mieszanie, długotrwały proces czyszczenia materiału z soli glauberskiej) należy uznać, że lepsza jest metoda zamrażania.

Uważny wybór metody wydzielania frakcji silt jest bardzo istotny. Nieprawidłowe wyznaczenie udziału frakcji silt prowadzi do zafałszowania wyników analiz w przypadku, gdy chcemy, uwzględnić parametry tej frakcji w modelu interpre- tacyjnym skały. Poniżej zestawiono wyniki analiz rentgenowskich pod kątem wyznaczenia zawartości minerałów we frakcji pylastej badanych próbek. Zauważa się wyraźne różnice zawartości kwarcu i minerałów ilastych w zależności od sposobu wydzielenia frakcji silt (rysunek 19).

Na rysunkach 20 i 21 zestawiono parametry (zawartość kwarcu i sumę minerałów ilastych) określone dla całej skały i jej części pylastej $(4 \div 63 \mu \mathrm{m})$ uzyskanej dwoma metodami: rozkruszania i zamrażania. Proporcje skała/silt otrzymane dla frakcji pylastej wydzielonej metodą zamrażania należy uznać za bardziej wiarygodne.

W analogiczny sposób przedstawiono wyniki pomiarów naturalnej promieniotwórczości frakcji pylastej oraz całej próbki. Celem wyznaczenia naturalnej promieniotwórczości całkowitej (GR) wykorzystano w obliczeniach wzór:

$$
\mathrm{GR}[\mathrm{API}]=16 \cdot \mathrm{K}[\%] \cdot 4 \cdot \mathrm{Th}[\mathrm{ppm}]+8 \cdot \mathrm{U}[\mathrm{ppm}]
$$

Poniżej zestawiono wyniki pomiarów naturalnej promieniotwórczości gamma - całkowitej (GR) i bezuranowej $(\mathrm{Th}+\mathrm{K})$, która często wykorzystywana jest $\mathrm{w}$ interpretacji pomiarów otworowych do szacowania wielkości zailenia. Podobnie jak 


\section{NAFTA-GAZ}

w przypadku analiz rentgenowskich, zauważa się wyraźne różnice uzyskanych wyników w zależności od sposobu wydzielenia frakcji silt (rysunki 22, 23, 24). Na rysunkach 23 i 24 zestawiono wyniki pomiarów naturalnej promieniotwórczości całkowitej i bezuranowej określone dla całej skały i jej części py- lastej $(4 \div 63 \mu \mathrm{m})$ uzyskanej metodą rozkruszania oraz metodą zamrażania. Podobnie jak w przypadku wyników ilościowej analizy rentgenowskiej, proporcje skała/silt otrzymane dla frakcji pylastej wydzielonej metodą zamrażania należy uznać za bardziej wiarygodne.
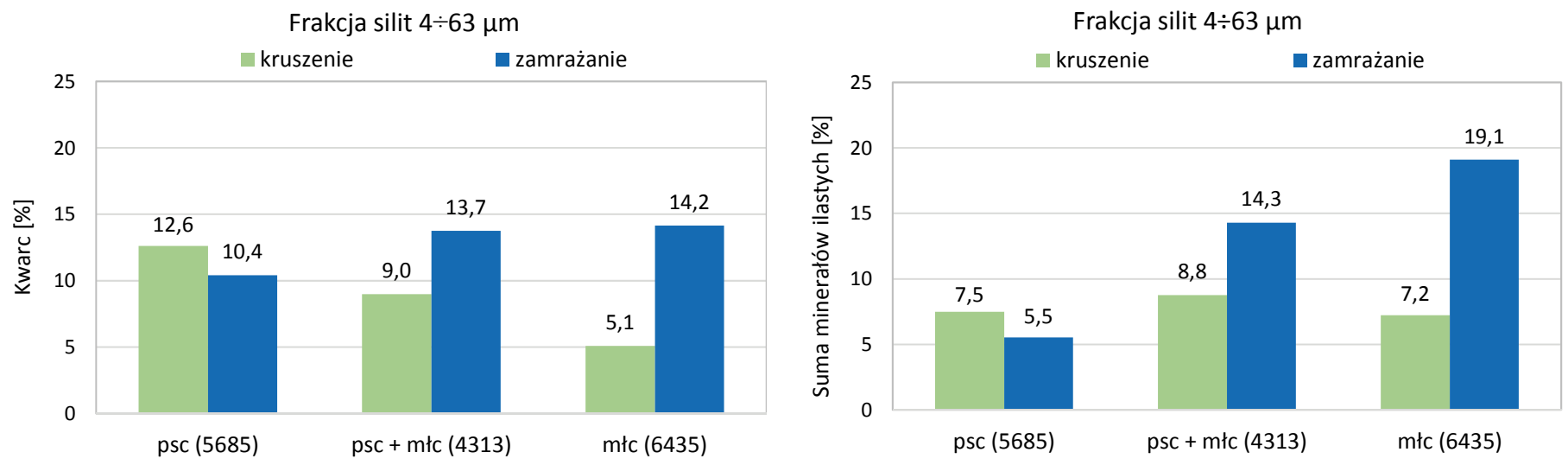

Rys. 19. Zestawienie wyników analizy XRD pod kątem określenia zawartości kwarcu i minerałów ilastych we frakcjach pylastych $(4 \div 63 \mu \mathrm{m})$ wydzielonych dla poszczególnych próbek metodą rozkruszania i metodą zamrażania
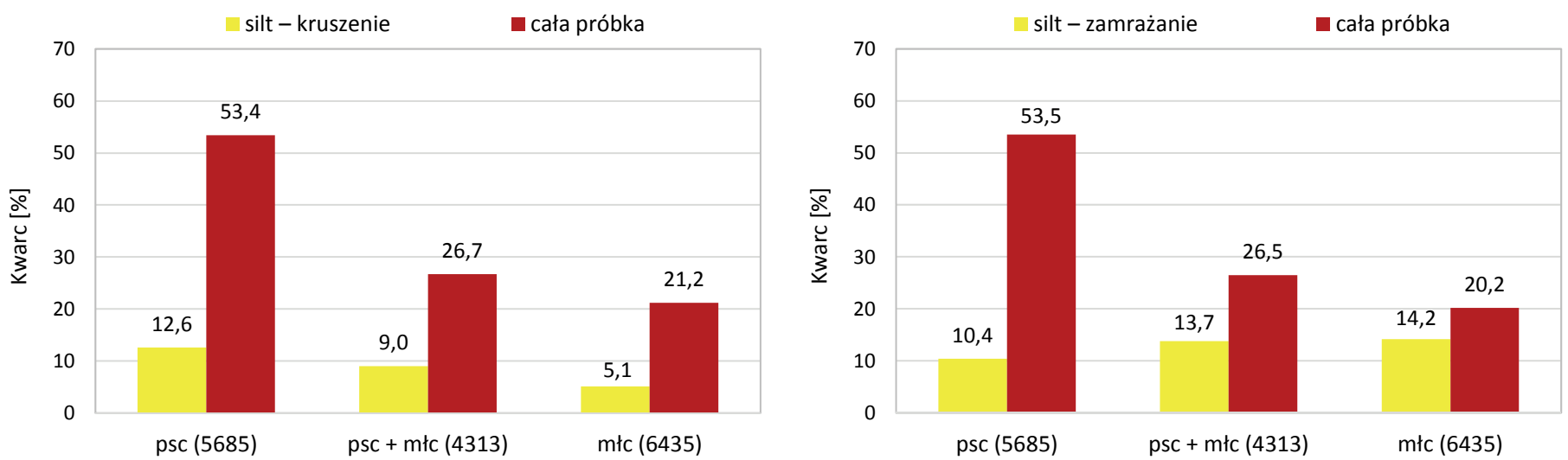

Rys. 20. Zawartość kwarcu określona dla całej skały i jej części pylastej $(4 \div 63 \mu \mathrm{m})$ uzyskanej metodą rozkruszania i metodą zamrażania
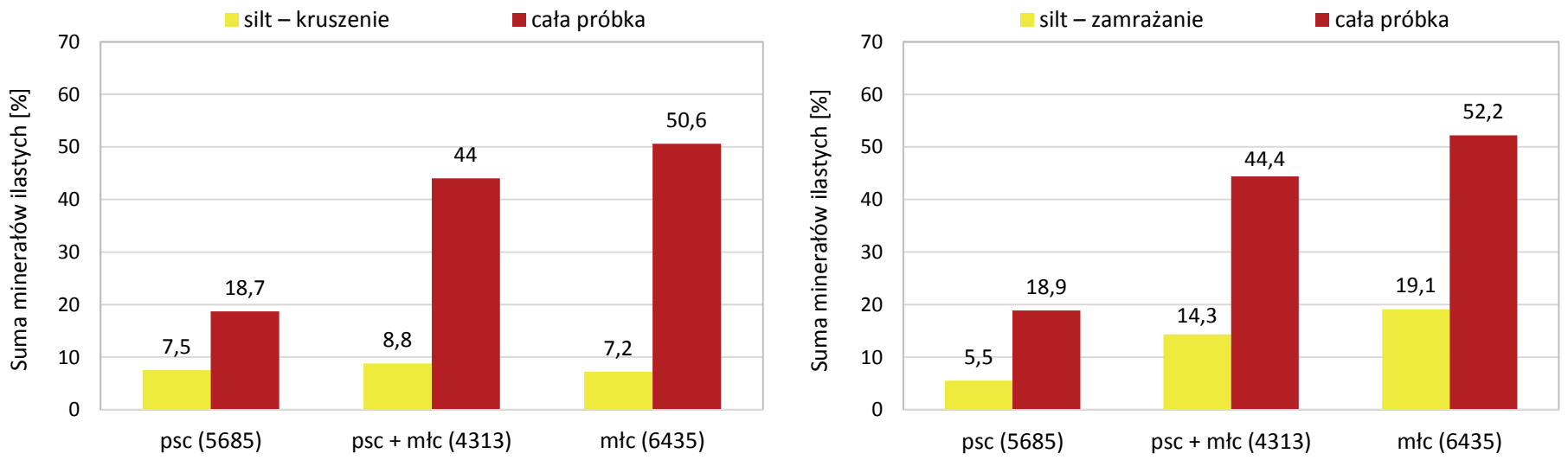

Rys. 21. Suma minerałów ilastych określona dla całej skały i jej części pylastej $(4 \div 63 \mu \mathrm{m})$ uzyskanej metodą rozkruszania i metodą zamrażania 

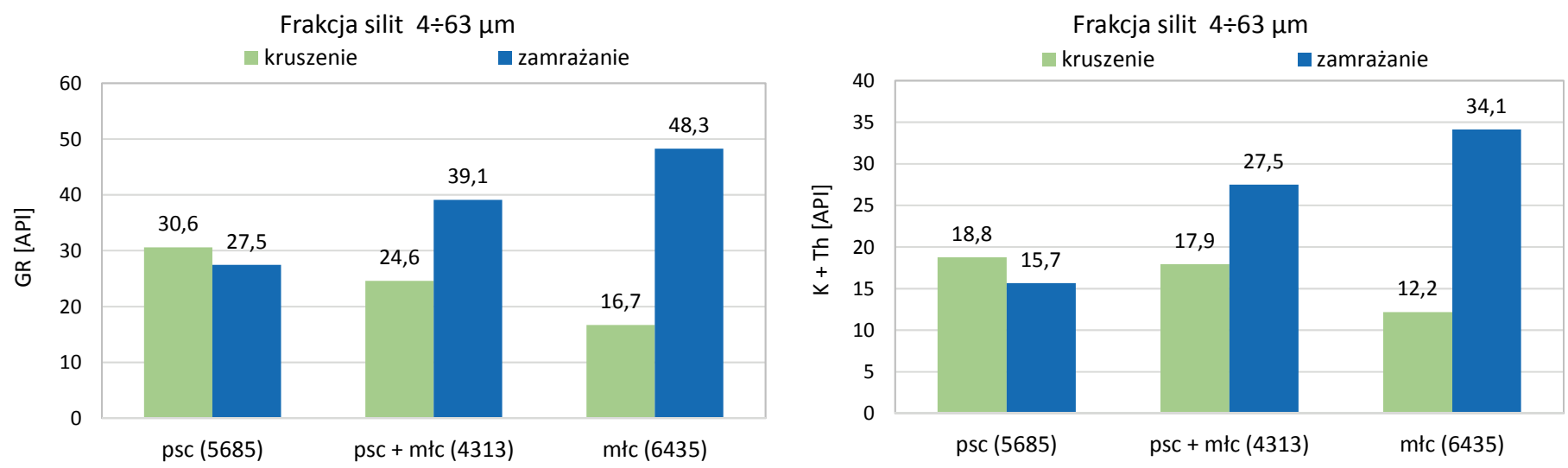

Rys. 22. Zestawienie wyników pomiarów radiometrycznych pod kątem określenia naturalnej promieniotwórczości całkowitej (GR) i bezuranowej $(\mathrm{K}+\mathrm{Th})$ frakcji pylastych $(4 \div 63 \mu \mathrm{m})$ wydzielonych dla poszczególnych próbek metodą rozkruszania i metodą zamrażania
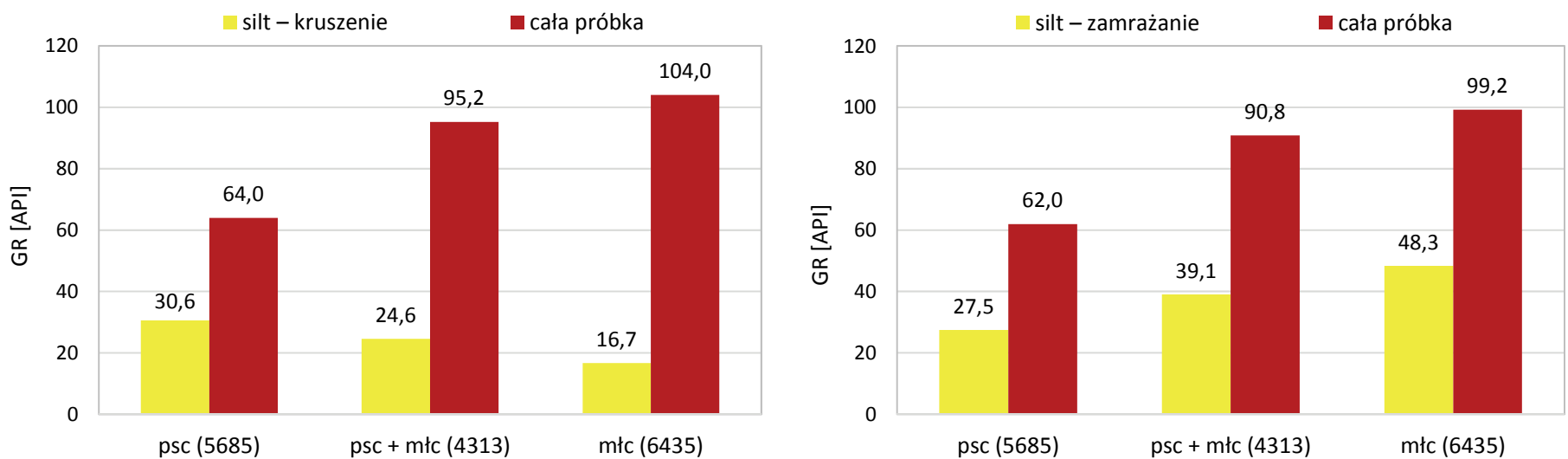

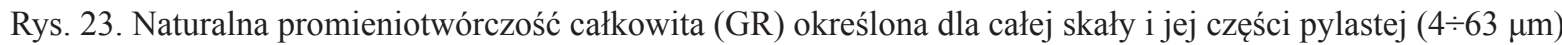
uzyskanej metodą rozkruszania i metodą zamrażania
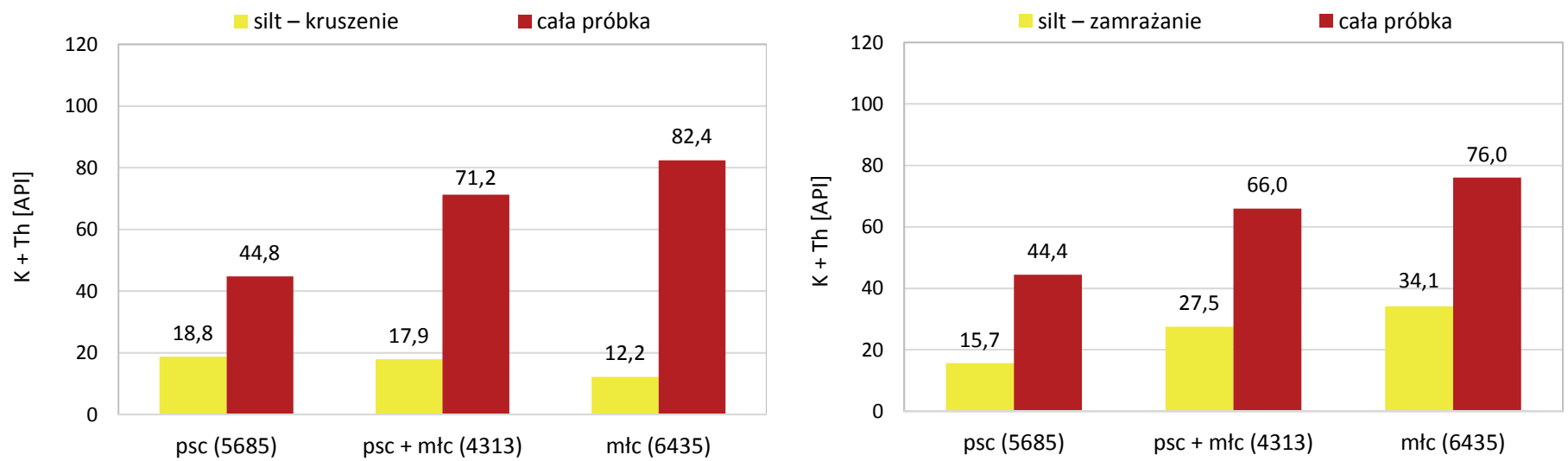

Rys. 24. Naturalna promieniotwórczość bezuranowa $(\mathrm{K}+\mathrm{Th})$ określona dla całej skały i jej części pylastej $(4 \div 63 \mu \mathrm{m})$ uzyskanej metodą rozkruszania i metodą zamrażania

W tablicy 4 zamieszczono wyniki pomiarów natural- $(4 \div 63 \mu \mathrm{m}) \mathrm{z}$ uwzględnieniem trzech metod wydzielania tej nej promieniotwórczości odniesionych do frakcji pylastej frakcji. 
Tablica 4. Naturalna promieniotwórczość frakcji pylastej $(4 \div 63 \mu \mathrm{m})$ z uwzględnieniem ilościowej zawartości frakcji W danej próbce określonej metodą rozkruszania, zamrażania i nasycania solą glauberską

\begin{tabular}{|c|c|c|c|c|c|c|c|c|}
\hline \multirow{2}{*}{ Litologia } & \multirow{2}{*}{$\begin{array}{l}\text { Numer } \\
\text { próbki }\end{array}$} & \multirow{2}{*}{\multicolumn{2}{|c|}{ Oznaczenie metody }} & \multirow{2}{*}{$\begin{array}{c}\mathrm{K} \\
\%] \\
\end{array}$} & \multirow{2}{*}{$\begin{array}{c}\mathrm{U}+\mathrm{Ra} \\
\mathrm{ppm}]\end{array}$} & \multirow{2}{*}{$\begin{array}{c}\mathrm{Th} \\
\mathrm{ppm}] \\
\end{array}$} & \multirow{2}{*}{$\frac{\mathrm{GR}}{[\mathrm{API}]}$} & \multirow{2}{*}{$\begin{array}{c}\frac{K+\mathrm{Th}}{[\mathrm{API}]} \\
\end{array}$} \\
\hline & & & & & & & & \\
\hline Piaskowiec & 5685 & $\mathrm{R}$ & rozkruszanie & 0,5 & 1,5 & 2,8 & 30,6 & 18,8 \\
\hline Piaskowiec & 5685 & $\mathrm{Z}$ & zamrażanie & 0,4 & 1,5 & 2,5 & 27,5 & 15,7 \\
\hline Piaskowiec & 5719 & $\mathrm{R}$ & rozkruszanie & 0,4 & 1,1 & 2,7 & 26,6 & 17,7 \\
\hline Piaskowiec & 5719 & SG & sól glauberska & 0,4 & 0,6 & 1,8 & 18,0 & 13,1 \\
\hline $\begin{array}{c}\text { Piaskowiec z wkł. } \\
\text { mułowca }\end{array}$ & 4313 & $\mathrm{R}$ & rozkruszanie & 0,5 & 0,8 & 2,3 & 24,6 & 17,9 \\
\hline $\begin{array}{c}\text { Piaskowiec z wkł. } \\
\text { mułowca }\end{array}$ & 4313 & Z & zamrażanie & 0,8 & 1,5 & 3,6 & 39,1 & 27,5 \\
\hline $\begin{array}{c}\text { Piaskowiec z wkł. } \\
\text { mułowca }\end{array}$ & $\mathrm{C}-3$ & $\mathrm{R}$ & rozkruszanie & 0,6 & 0,9 & 2,4 & 25,4 & 18,4 \\
\hline $\begin{array}{c}\text { Piaskowiec z wkł. } \\
\text { mułowca }\end{array}$ & $\mathrm{C}-3$ & SG & sól glauberska & 1,0 & 1,8 & 4,6 & 49,2 & 34,8 \\
\hline Mułowiec & 6435 & $\mathrm{R}-\mathrm{Z}$ & rozkruszanie & 0,3 & 0,6 & 1,7 & 16,7 & 12,2 \\
\hline Mułowiec & 6435 & $\mathrm{Z}$ & zamrażanie & 1,1 & 1,8 & 4,2 & 48,3 & 34,1 \\
\hline Mułowiec & 6435 & R-SG & rozkruszanie & 0,5 & 0,7 & 2,0 & 21,3 & 15,5 \\
\hline Mułowiec & 6435 & SG & sól glauberska & 1,0 & 1,4 & 3,7 & 41,6 & 30,1 \\
\hline
\end{tabular}

\section{Podsumowanie i wnioski}

Głównym zadaniem przedstawionych badań było stworzenie metodyki pozwalającej na wydzielenie, charakterystykę i oszacowanie ilościowego udziału frakcji pylastej (silt) w skałach mułowcowych. Przetestowano różne metody laboratoryjnego wydzielania frakcji pylastej (rozkruszanie, zamrażanie, nasycanie solą glauberską). Badania skaningowe potwierdziły, że wszystkie metody umożliwiają uzyskanie frakcji pylastej $(4 \div 63 \mu \mathrm{m})$ pod kątem wielkości ziaren. Niemniej jednak dopiero odpowiedni dobór materiału skalnego, który uwzględniał różne typy litologiczne skał piaszczysto-ilastych, tj. piaskowiec, mułowiec z wkładkami piaskowca i mułowiec, umożliwił analizę ilościowych udziałów różnych frakcji, pod kątem weryfikacji metody wydzielania frakcji pylastej. Za najlepszą uznano metodę zamrażania. Taki wybór potwierdziły uzyskane proporcje zarówno frakcji piaszczystej ( $>63 \mu \mathrm{m})$, jak i pylastej $(4 \div 63 \mu \mathrm{m})$ dla badanych litotypów. Również parametry frakcji pylastej takie jak: suma minerałów ilastych, zawartość kwarcu, naturalna promieniotwórczość, wyznaczone przez uwzględnienie ilościowego udziału tej frakcji w skale metodą zamrażania, logicznie wpisują się w poszczególne litotypy.

Na podstawie przeprowadzonych badań mineralogicznych zaobserwowano, że jakościowy skład mineralny wydzielonej frakcji pylastej (silt) nie różni się znacząco od składu próbki wyjściowej. Jest zubożony o grubokrystaliczny kwarc i minerał mieszanopakietowy (pęczniejący) illit-smektyt. Skład mineralny próbki, jaki określono metodą XRD, został potwierdzony na podstawie analizy XRF oraz punktowych analiz składu chemicznego wykonanych przy pomocy mikrosondy (obserwacje skaningowe).

Wydzielenie frakcji pylastej metodą laboratoryjną w skałach piaszczysto-ilastych zapadliska przedkarpackiego umożliwi ilościową ocenę zawartości tej frakcji w badanej skale i określenie jej właściwości fizykochemicznych. Znajomość parametrów charakteryzujących frakcję pylastą daje szanse na uwzględnienie tej frakcji w modelu interpretacyjnym skały, a tym samym na bardziej wiarygodne oszacowanie wielkości zailenia. Ma to decydujące znaczenie dla oceny ważnych parametrów złożowych, takich jak: porowatość efektywna i nasycenie mediami złożowymi.

Z punktu widzenia tworzenia modelu interpretacyjnego skały, w którym będzie można uwzględnić parametry frakcji pylastej, istotne wydaje się również wydzielenie i scharakteryzowanie udziału frakcji ilastej. Następnym etapem byłaby również separacja minerałów ciężkich (niewidocznych na XRD, ale widocznych na skaningu), w celu sprawdzenia ich wpływu na zawartość toru. Badania będą kontynuowane. 
Prosimy cytować jako: Nafta-Gaz 2018, nr 4, s. 259-269, DOI: 10.18668/NG.2018.04.01

Artykuł nadesłano do Redakcji 24.11.2018 r. Zatwierdzono do druku 6.03.2018 r.

Artykuł powstał na podstawie pracy statutowej pt.: Wydzielanie i charakterystyka frakcji pylastej (silt) w skałach mułowcowych zapadliska przedkarpackiego - praca INiG - PIB na zlecenie MNiSW; nr zlecenia: 0029/SW, nr archiwalny: DK-4100-16/17.

\section{Literatura}

[1] Gąsior I., Skupio R., Przelaskowska A., Orzechowski M., Zagórska U., Dohnalik M., Kowalska S.: Wykorzystanie pomiarów naturalnej promieniotwórczości skał z zastosowaniem spektrometru Gamma Logger oraz spektrometru Mazar do określenia zailenia utworów starszego paleozoiku. Nafta-Gaz 2016, nr 10, s. 790-798, DOI: 10.18668/NG.2016.10.03.

[2] Kaim A.: Metody maceracji skat stabo zlityfikowanych. Kurs preparacji skamieniałości. Instytut Paleobiologii PAN, Warszawa 2000.

[3] Kowalska S.: Instrukcja wydzielania frakcji ilastej. IS-06/ SW-1, wyd. nr 2 z 01.02.2004.

[4] Kowalska S.: Określenie ilościowego składu mineralnego skat zawierajacych mineraty ilaste metoda Rietvelda. Nafta-Gaz 2013, nr 12, s. 894-902.

[5] Kowalska S.: Procedura identyfikacji minerałów ilastych metoda rentgenowskiej analizy fazowej. PBN-05/SW-1, wyd. nr 2 z 01.02.2004.

[6] Manecki A., Muszyński M.: Rozdzielanie minerałów. Mineralogia. Materiały dydaktyczne AGH, Kraków, 2005.

[7] Peveraro R., Thomas E.C.: Effective porosity: A defensible definition for shaly sand. SPWLA $51^{\text {st }}$ Annual Logging Symposium, Australia 19-23.06.2010.

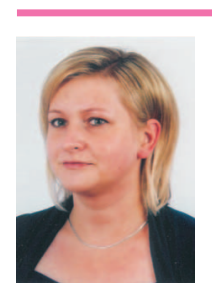

Mgr inż. Grażyna ŁYKOWSKA

Starszy specjalista inżynieryjno-techniczny

w Zakładzie Geofizyki Wiertniczej; kierownik ds.

Jakości Laboratorium Geofizycznych Parametrów

Skał i Płynów Złożowych.

Instytut Nafty i Gazu - Państwowy Instytut Badawczy

ul. Lubicz 25A, 31-503 Kraków

E-mail: grazyna.lykowska@inig.pl

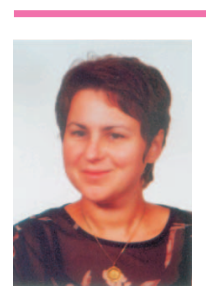

Mgr Anna PRZELASKOWSKA

Starszy specjalista badawczo-techniczny

w Zakładzie Geofizyki Wiertniczej.

Instytut Nafty i Gazu - Państwowy Instytut Badawczy

ul. Lubicz $25 \mathrm{~A}$

31-503 Kraków

E-mail: anna.przelaskowska@inig.pl
[8] Przelaskowska A., Klaja J.: Pomiary pojemności wymiany kationowej (CEC) w badaniach skat osadowych. Nafta-Gaz 2014, nr 7, s. 432-438.

[9] Schon J. H.: Physical Properties of Rocks: A Workbook. Handbook of Petroleum Exploration and Production, vol. 8. Elsevier 2011.

[10] Skupio R.: Wykorzystanie przenośnego spektrometru XRF do pomiarów składu chemicznego skat. Nafta-Gaz 2014, nr 11, s. 771-777.

[11] Szmańda J.B., Krzemień K.: Uwagi na temat wybranych klasyfikacji frakcjonalnych osadów klastycznych - problem róznic w przedziałach klasowych i nazewnictwie. Landform Analysis 2008, vol. 9, s. 381-384.

[12] USGS: Separation of the silt and clay fractions for X-Ray powder diffraction by centrifugation. Coastal and Marine Geology Program, 2001. U.S. Geological Survey Open File Report 01-041.

[13] Wenthworth C.K.: A scale of grade and class terms for clastic sediments. The Journal of Geology 1922, vol. 30, s. 377-392.

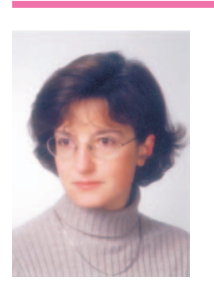

Mgr inż. Jolanta KLAJA

Starszy specjalista badawczo-techniczny

w Zakładzie Geofizyki Wiertniczej.

Instytut Nafty i Gazu - Państwowy Instytut Badawczy ul. Lubicz 25 A

31-503 Kraków

E-mail: jolanta.klaja@inig.pl

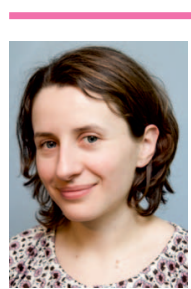

Mgr Urszula ZAGÓRSKA

Asystent w Zakładzie Geofizyki Wiertniczej.

Instytut Nafty i Gazu - Państwowy Instytut Badawczy

ul. Lubicz 25 A

31-503 Kraków

E-mail: urszula.jonkis@inig.pl 